\title{
Efficacy of Some Plant Extracts in Controlling Seed-Borne Fungal Infections of Mustard
}

\author{
M Abdul Latif ${ }^{1 *}$, Abu Kaoser M Saleh ${ }^{1}$, M Ashik Iqbal Khan ${ }^{3}$, Habibur Rahman ${ }^{4}$ and M Anwar Hossain ${ }^{1}$ \\ ${ }^{1}$ Plant Pathology Division, Bangladesh Rice Research Institute (BRRI), Joydebpur, Gazipur 1701, Bangladesh, ${ }^{2}$ Kazi Farms Limited, Poduar Bazer, \\ Comilla 3500, Bangladesh, ${ }^{3}$ Regional Station, Bangladesh Rice Research Institute (BRRI), Barisal 8200, Bangladesh, ${ }^{4}$ Department of Plant \\ Pathology, Potuakhali Science \& Technology University, Potukhali, Bangladesh
}

[Received 06 September 2006; Accepted 07 October 2006]

\begin{abstract}
Efficacy of various concentrations of four plant extracts prepared from garlic, Neem leaf, ginger and onion bulb on reduction of seed-borne fungi was evaluated. Among the treatments, garlic extract preparations (1:0, $1: 1$ and $1: 2)$ and fungicide Rovral $(0.25 \%$ of seed weight) had shown to enhance seed germination remarkably compared to the other treatment. The percent reduction of fungal incidence achieved with three concentrations

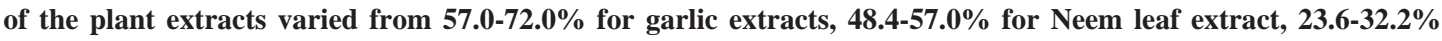
for ginger extract, and 10.7-15.1 for onion bulb extract. The fungi isolated from the mustard seeds included species of Alternaria, Aspergillus, Chaetomium, Curvularia, Fusarium, Penicillium and Rhizopus. It was also found that garlic extract was most effective in controlling the seed-borne fungi among the plant extracts studies. The effectiveness of concentrated (1:0) preparation of garlic extract was comparable to the fungicide Rovral. In addition, Neem leaf extract was moderately effective in removal of mycoflora of mustard seeds, while ginger and onion bulb extracts were the least effective in removal of the seed-borne fungi.
\end{abstract}

Keywords: Mustard, Seed-borne fungi, Plant extracts, Seed germination, Control of seed-borne fungi

Mustard (Brassica campestris L) is widely grown oilseed crop in Bangladesh. It suffers from as many as eleven different diseases ${ }^{1}$. At present there occurs at least 8 diseases of mustard in the country. Crop loss between $30-100 \%$ due to these diseases has been reported ${ }^{2}$. It has been reported that the diseases cause heavy loss to the crop and reducing crop yield to an extent of $30-40 \%{ }^{3-4}$. Efforts have been and are still being made to control the disease by developing resistance in the host ${ }^{5-6}$. In absence of resistantsources, chemicals especially the farmers have been using foliar fungicides that provoke environmental pollution. Alternatives to chemicals are, therefore, sought. Control of seed-borne diseases of mustard with chemicals is also expensive to our poor farmers. Since crude extracts of plant can be easily prepared and there are many reports of their use as biocides ${ }^{7}$. In the view of above, the present investigation was under taken to determine the efficacy of plant extracts in controlling the seed-borne fungal flora in mustard.

The experiments were conducted at the Department of Plant Pathology, Bangladesh Agricultural University (BAU), Mymensingh, Bangladesh. Seed samples of mustard variety, Sonali Sarisha, were collected directly from the farmers of four locations of Dhaka Division. The seeds were mixed up and a composite sample of mustard was used for this study. Plants extracts were prepared from garlic (Allium sativum), Neem leaf (Azadirachta indica), ginger (Zingiber officinale), and onion bulb (Allium cepa). The plant materials (40 g) were ground in a mortar with a pestle and the slurries were filtered and stored in a refrigerator at $4^{\circ} \mathrm{C}$ until use. Mustard seeds were treated for $30 \mathrm{~min}$ to $4 \mathrm{~h}$ by dipping the seeds in the plant extracts. The experiments were also performed with a fungicide Rovral @ 0.25\% of seed weight. Two hundred seeds per treatment were tested and the mean results were recorded. The treated seed samples were examined for the presence of fungal flora by blotter method following the international rules for seed testing ${ }^{8}$. The incidence of fungi and percent germination of seed were observed after 7 days of incubation at room temperature.

The overall incidence of fungal infection of the untreated (control) seeds was $31.0 \%$. Table 1 summarizes the effect of plant extracts and fungicide (Rovral) on seed germination and reduction of incidence of fungal infection. The plants extracts had profound effect on the germination of mustard seed. The germination ability of the seeds of control group (without plant extract or fungicide) was $65 \%$, while that of the seeds treated with the fungicide or garlic extract (1:1) was 76\%. The germination ability varied from $72-76 \%$ when seeds were pretreated with various concentrations of garlic extracts. In case of Neem leaf, ginger and onion bulb extracts the germination ability varied from $65-70 \%, 65-69 \%$ and $65-69 \%$ respectively. The percent reduction of seed-borne fungi treated with different plant extracts varied between $11.7 \%$ (onion bulb extract) and $72.0 \%$ (garlic extract) depending on the concentration of the extract preparations. Among the plant extracts used, garlic extracts was found to most effective in removal of

*Corresponding author:

Dr. M Abdul Latif, Senior Scientific Officer, Plant Pathology Division, Bangladesh Rice Research Institute (BRRI), Joydebpur, Gazipur 1701, Bangladesh Tel (Office): (02) 9257401-5/398; Tel (Home): (02) 9257401-5/300; Cell: 0171 5034094; E-mail: alatif1965@yahoo.com 
Table 1. Effectiveness of treatment with different plant extracts and fungicide Rovral on germination and reduction of fungal incidence of mustard seeds

\begin{tabular}{|c|c|c|c|}
\hline $\begin{array}{l}\text { Treatment } \\
\text { (extract: } \\
\text { water ratio) }\end{array}$ & $\begin{array}{c}\text { Seed } \\
\text { germination } \\
(\%)\end{array}$ & $\begin{array}{l}\text { Incidence }(\%) \\
\text { of fungus-prone } \\
\text { seeds after } \\
\text { treatment for } \\
0.5 / 1.0 / 2.0 \mathrm{~h} \\
\text { (Average) }\end{array}$ & $\begin{array}{c}\text { Percent } \\
\text { reduction } \\
\text { of fungus- } \\
\text { prone } \\
\text { seeds }\end{array}$ \\
\hline Garlic (1:0) & 76 & 10/9/7 (8.7) & 72.0 \\
\hline Garlic (1:1) & 74 & $13 / 12 / 8(11.0)$ & 64.5 \\
\hline Garlic (1:2) & 72 & $15 / 14 / 11(13.3)$ & 57.0 \\
\hline Neem leaf (1:0) & 70 & 17/12/11 (13.3) & 57.0 \\
\hline Neem leaf (1:1) & 69 & 21/13/12 (15.3) & 50.5 \\
\hline Neem leaf (1:2) & 65 & 19/15/14 (16.0) & 48.4 \\
\hline Ginger (1:0) & 69 & 26/19/18 (21.0) & 32.2 \\
\hline Ginger (1:1) & 65 & 28/23/19 (23.3) & 24.7 \\
\hline Ginger (1:2) & 65 & $25 / 24 / 22(23.7)$ & 23.6 \\
\hline Onion (1:0) & 68 & 29/25/25 (26.3) & 15.1 \\
\hline Onion (1:1) & 65 & $30 / 27 / 26(27.7)$ & 10.7 \\
\hline Onion (1:2) & 69 & $27 / 27 / 29(27 / 7)$ & 10.7 \\
\hline Rovral (fungicide) $^{*}$ & 76 & - (8.0) & 74.2 \\
\hline Control & 65 & - (31.0) & - \\
\hline
\end{tabular}

*At a concentration of $0.25 \%$ of seed weight seed-borne fungi. The incidence of fungal infection reduced by $57.0-72.0 \%$ with garlic extract. Neem leaf extract was also effective in removal of seed-brine fungi, which reduced the incidence by 48.4-57.0\%. Ginger and onion bulb extracts were least effective in controlling the seed-borne fungal infections, which corresponded to $23.6-32.3 \%$ reduction and $10.7-15.1 \%$ reduction of the fungal incidences.

Table 2 summarizes the fungi isolated from mustard seeds and their sensitivity to various concentrations of the plant extract. Seven different fungi were identified from the mustard seeds including the species of Alternaria, Aspergillus, Chaetomium, Curvularia, Fusarium, Penicillium and Rhizopus. Among them Alternaria, Fusarium and Aspergillus were most prevalent. The fungal infections by these types fungi were also reported by other investigators ${ }^{9}$. The incidence of seed infection by different fungi decreased remarkable by treatment of seeds with the crude garlic extract, which was comparable to the chemical fungicide Rovral. Therefore, garlic extract seems promising and could be used by farmers in controlling seed-borne fungi. These results agree with Rahman ${ }^{10}$ and Alice and Rao ${ }^{11}$ who also reported on the effectiveness of garlic extracts for the control of seed-borne fungus Drechslera oryzae. In this study, Neem leaf extracts also reduced the different mycoflora but its effect was much less than that achieved with the garlic extract. Ginger and onion bulb extracts were not effective in the control fungal flora compare to the fungicide Rovral or garlic extract.

Table 2. Fungi isolated from infected mustard seeds and the effectiveness of treatment with different plant extracts and fungicide Rovral on removal of the various fungi from the seeds

\begin{tabular}{|c|c|c|c|c|c|c|c|}
\hline \multirow{2}{*}{$\begin{array}{l}\text { Treatment } \\
\text { (extract : water ratio) }\end{array}$} & \multicolumn{7}{|c|}{ Incidence (\%) of fungus-prone seeds after treatment for $0.5 / 1.0 / 4.0 \mathrm{~h}$} \\
\hline & Alternaria & Aspergillus & Chaetomium & Curvularia & Fusarium & Penicillium & Rhizopus \\
\hline Garlic (1:0) & $3 / 3 / 2$ & $2 / 2 / 2$ & $0 / 0 / 1$ & $1 / 1 / 0$ & $4 / 2 / 2$ & $0 / 1 / 1$ & $0 / 0 / 0$ \\
\hline Garlic (1:1) & $4 / 3 / 3$ & $2 / 2 / 1$ & $0 / 1 / 1$ & $0 / 0 / 0$ & $3 / 2 / 2$ & $2 / 2 / 0$ & $1 / 1 / 1$ \\
\hline Garlic (1:2) & $5 / 5 / 4$ & $2 / 2 / 2$ & $1 / 0 / 0$ & $0 / 1 / 1$ & $4 / 4 / 3$ & $1 / 1 / 1$ & $2 / 1 / 0$ \\
\hline Neem (1:0) & $6 / 4 / 4$ & $2 / 1 / 1$ & $2 / 1 / 0$ & $1 / 0 / 0$ & 3/3/3 & $2 / 1 / 2$ & $1 / 2 / 1$ \\
\hline Neem (1:1) & $7 / 6 / 5$ & $4 / 3 / 2$ & $1 / 0 / 1$ & $2 / 0 / 1$ & $4 / 2 / 2$ & $1 / 1 / 0$ & $2 / 1 / 1$ \\
\hline Neem (1:2) & $5 / 6 / 7$ & $2 / 2 / 1$ & $1 / 1 / 1$ & $1 / 1 / 1$ & $2 / 2 / 2$ & $0 / 0 / 2$ & $1 / 1 / 0$ \\
\hline Ginger (1:0) & $7 / 7 / 7$ & $8 / 5 / 4$ & $0 / 1 / 1$ & $1 / 0 / 0$ & $6 / 6 / 4$ & $3 / 0 / 1$ & $1 / 0 / 2$ \\
\hline Ginger (1:1) & 8/7/7 & $7 / 6 / 6$ & $0 / 0 / 0$ & $1 / 1 / 1$ & $9 / 7 / 3$ & $1 / 2 / 0$ & $2 / 0 / 2$ \\
\hline Ginger (1:2) & $9 / 8 / 7$ & $5 / 7 / 5$ & $2 / 1 / 2$ & $0 / 0 / 1$ & $7 / 6 / 4$ & $1 / 1 / 2$ & $1 / 1 / 1$ \\
\hline Onion (1:0) & 9/9/9 & $7 / 5 / 6$ & $1 / 1 / 1$ & $1 / 01$ & 8/8/6 & $1 / 1 / 2$ & $2 / 1 / 0$ \\
\hline Onion (1:1) & 8/7/1 & $7 / 7 / 6$ & $1 / 1 / 1$ & $1 / 1 / 1$ & 9/9/7 & $2 / 0 / 2$ & $2 / 2 / 1$ \\
\hline Onion (1:2) & $11 / 8 / 8$ & $6 / 6 / 8$ & $1 / 2 / 0$ & $1 / 1 / 1$ & $7 / 8 / 9$ & $0 / 1 / 1$ & $1 / 1 / 0$ \\
\hline Rovral $^{*}$ & 2 & 2 & 0 & 0 & 3 & 0 & 1 \\
\hline Control & 10 & 7 & 1 & 1 & 8 & 2 & 2 \\
\hline
\end{tabular}

*At a concentration of $0.25 \%$ of seed weight 
It was also found in this study that treatment time was important in controlling seed-borne fungi using various plant extracts. Figure 1 shows the relationship between garlic extract treatment period and reduction of most prevalent seed-borne fungus, Alternaria. A negative linear relationship ( $r=-0.922$ ) between incidence of Alternaria and soaking period was observed, that is, the incidence decreased with the increase of treatment period.

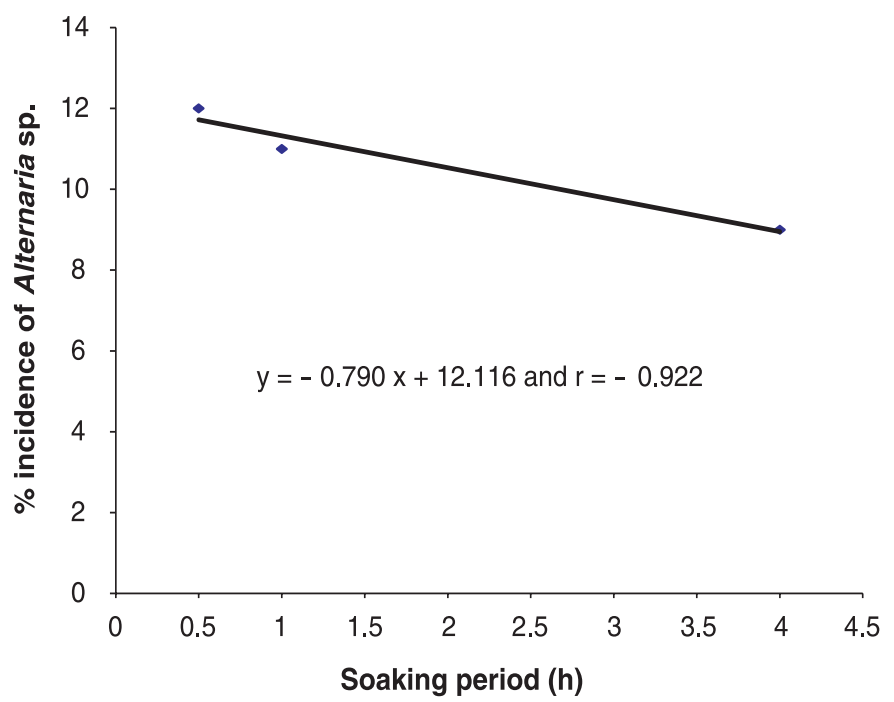

Figure 1. Relationship between incidence of infection with Alternaria and period of treatment with garlic extract of mustard seeds.

The study clearly demonstrated that some plants extracts, particularly garlic extract, are effective in controlling the seed- borne fungi from mustard seed. Garlic, a cheap and readily available spice used by people, could be used by farmers to reduce the incidence of diseases of mustard.

\section{References}

1. Rangaswami G. 1979. Diseases of Crop Plants in India, $2^{\text {nd }}$ edn. Prentice-Hall, New Delhi.

2. Meah MB, Howlider MAR and Alam MK. 1988. Effect of fungicides spray at different time and frequency on Alternaria blight of mustard. Thai J Agric Sci. 21: 101-107.

3. Rai B, Kolte SI \& Tewari AN. 1976. Evaluation of oleferous Brassica germplasm for resistance to Alternaria leaf blight. Indian Phytopathol. 29: 76-77.

4. Fakir GA. 1980. Balktrita Sankalan. Saisha Sangrakkhan Prashikhan. Publication No. 14, pp 163-164. Graduate Training Institute, Bangladesh Agricultural University, Mymensingh.

5. Bhander DS \& Maini NS. 1965. Studies on the resistant of oleiferous brassicas to Alternaria blight. Indian Oilseeds J. 9: 58-60.

6. Anonymous. 1983. Annual Report, p 55. Plant Pathology Division, Bangladesh Rice Research Institute (BRRI), Joydebpur, Gazipur.

7. Shethy SA, Prakash HS \& Shetty HS. 1990. Efficiency of certain plant extracts against seed borne infection of Trichoniella padwickii in paddy. Rice Abstract. 13(6): 330.

8. ISTA. 1976. International rules for seed testing. International Seed Testing Association (ISTA). Seed Sci Technol. 4: 51-177.

9. Anonymous. 1984. Annual Report, p 100. Plant Pathology Division, Bangladesh Rice Research Institute (BRRI), Joydebpur, Gazipur.

10. Rahman M. 1992. Study on the seed-borne fungi and their control with botanical and chemical fungicides on five local Boro varieties of rice. MSc Thesis. Department of Plant Pathology, Bangladesh Agricultural University, Mymensingh.

11. Alice D \& Rao AV. 1986. Management of seed-borne Drechslera oryzae of rice with plant extracts. Int Rice Res Newsl. 11: 19-24. 